7. Reprod. Fert. (1966) 12, 565-567

BRIEF COMMUNICATION

\title{
THE STIMULATION OF FERTILE OESTRUS IN ANOESTROUS ROMNEY EWES. II
}

\author{
E. M. ROBERTS AND D. G. EDGAR \\ University of New South Wales, Kensington, N.S.W., Australia, and \\ Ruakura Agricultural Research Centre, Hamilton, New Zealand
}

(Received 9th April 1966)

\begin{abstract}
Summary. One hundred 6- and 7-year-old Romney ewes were treated for 13 days in January (mid-summer) with intra-vaginal sponges containing $40 \mathrm{mg}$ of 6-methyl-17-acetoxyprogesterone (MAP). All ewes received 1000 i.u. pregnant mares serum gonadotrophin (PMSG) on the day of sponge removal and fifty ewes received a second 1000 i.u. PMSG 16 days later.

The onset of oestrus was synchronized in both treatment groups and was apparently 2 weeks earlier than in twenty untreated ewes.

Lambs born as percentage of ewes surviving was satisfactory in all groups being: one dose of PMSG, 94\%; two doses of PMSG, $106 \%$; controls $105 \%$.
\end{abstract}

The use of intra-vaginal sponges containing $40 \mathrm{mg}$ of 6-methyl-17-acetoxyprogesterone (MAP) in conjunction with PMSG has been reported by Roberts \& Edgar (1966) as a method of progestational priming to induce fertile oestrus in anoestrous Romney ewes. The trial was conducted during December with lambing from treated ewes occurring during May and June.

The aims of the present trial were to examine with a larger number of ewes, the value of a 13-day period of MAP treatment, and to examine the effect of a second injection of PMSG given 16 days after the first.

One hundred and twenty 6- and 7-year-old Romney ewes which had been shorn and weaned of their lambs in early December were divided at random into three groups.

Group 1. Fifty ewes treated with intra-vaginal sponges containing $40 \mathrm{mg}$ MAP followed by 1000 i.u. of PMSG (Gestyl, Organon Laboratories Ltd.) injected subcutaneously on Day 13 when the sponges were removed.

Group 2. Fifty ewes treated for 13 days with intra-vaginal sponges containing $40 \mathrm{mg}$ MAP followed by 1000 i.u. of PMSG injected subcutaneously on Days 13 and 29.

Group 3. Twenty untreated ewes.

The sponges were inserted on 15th January 1965 (Day 0) and the ewes were run with six crayon-harnessed Southdown rams until 31 st March (Day 75). 
The ewes were maintained under the experimental and management conditions described by Roberts \& Edgar (1966), with mating and lambing recorded daily.

The patterns of oestrus for the three groups are presented in Table 1.

In both Groups 1 and 2 there is a highly synchronized incidence of oestrus in the 3 days following the first PMSG treatment, forty-three of fifty and fortyseven of fifty of the ewes respectively being marked by rams. The mean intervals to mating are shown in Table 1. They are similar for Groups 1 and 2 as also are their standard deviations. The mean intervals, however, are 13 to 14

\section{TABLE 1}

OESTRUS AND LAMBING PERFORMANCE OF ANOESTROUS ROMNEY EWES FOLLOWING TREATMENT DURING THE SUMMER WITH MAP AND PMSG

\begin{tabular}{|c|c|c|c|c|c|c|c|c|c|}
\hline \multirow[t]{2}{*}{$\begin{array}{l}\text { Group } \\
\text { No. }\end{array}$} & \multirow{2}{*}{$\begin{array}{c}\text { PMSG } \\
\text { in- } \\
\text { jections }\end{array}$} & \multirow{2}{*}{$\begin{array}{l}\text { No. of } \\
\text { ewes } \\
\text { surviv- } \\
\text { ing to } \\
\text { lambing }\end{array}$} & \multirow{2}{*}{$\begin{array}{c}\text { No. of } \\
\text { ewes } \\
\text { mating } \\
\text { after } \\
\text { first } \\
\text { PMSG } \\
\text { Days } \\
15 \text { to } 17\end{array}$} & \multicolumn{2}{|c|}{$\begin{array}{l}\text { Days to first } \\
\text { mating }\end{array}$} & \multirow{2}{*}{$\begin{array}{c}\text { Mean } \\
\text { lambing } \\
\text { day }\end{array}$} & \multirow{2}{*}{$\begin{array}{l}\text { Ewes lamb- } \\
\text { ing to mating } \\
\text { at time of } \\
\text { first } \mathrm{PMSG}\end{array}$} & \multirow[t]{2}{*}{$\begin{array}{l}\text { Total ewes } \\
\text { lambing }\end{array}$} & \multirow[t]{2}{*}{$\begin{array}{l}\text { Total lambs } \\
\quad \text { born }\end{array}$} \\
\hline & & & & Mean & $\sigma$ & & & & \\
\hline $\begin{array}{l}1 \\
2 \\
3\end{array}$ & $\begin{array}{l}1 \\
2 \\
0\end{array}$ & $\begin{array}{l}50 \\
49 \\
19\end{array}$ & $\begin{array}{l}43 \\
47 \\
-\end{array}$ & $\begin{array}{l}16 \cdot 94 \\
15 \cdot 25 \\
30 \cdot 1\end{array}$ & $\begin{array}{r}8.92 \\
3.92 \\
10 \cdot 56\end{array}$ & $\begin{array}{l}167.9 \\
172 \cdot 3 \\
179.7\end{array}$ & $\begin{array}{l}25(50 \% *) \\
36(73.5 \%) \\
13(68.4 \%)\end{array}$ & $\begin{array}{l}42(84 \%) \\
46(93.8 \%) \\
19(100 \%)\end{array}$ & $\begin{array}{l}47(94 \%) \\
52(106.1 \%) \\
21(110.5 \%)\end{array}$ \\
\hline
\end{tabular}

* Of number of ewes surviving.

days shorter than that of the Group 3, the untreated ewes. By Day 75, all ewes in each group had mated at least once.

It is apparent that in both treated groups a high percentage of ewes lambed before the date of lambing of the untreated ewes.

Table 1 shows that when the lambing period is divided into sections the number of ewes lambing to mating at the time of the first PMSG injection is different in each group. However, when the percentage of ewes lambing to mating at the first and second oestrus periods is calculated there are no significant differences for Groups 1 and $2(80 \%$ versus $84 \%)$.

The mean mating date of Group 3,11 days after Groups 1 and 2, indicates that the breeding season is about to commence. It might be expected, therefore, that the administration of 1000 i.u. of PMSG would result in multiple ovulations and births. There were, however, no significant differences, between any groups, in the percentage of twin births.

To assess the degree that synchronization at oestrus has been retained at lambing, it is necessary to study the peaks of oestrus and lambing equivalent to the first PMSG injection. In Group 2, forty-seven of fifty ewes mated during the 3 days from 30th January to 1st February. Of these thirty-six conceived but lambed over a period of 10 days. In Group 1, forty-three ewes were mated in the 3 days and twenty-five of these lambed over 8 days. In the former group 
there was a gap of 9 days, while in the latter 5 days elapsed before any further ewes lambed.

The findings provide further evidence of the value of treatment with MAP and PMSG for the synchronization of oestrus and suggest that the treatment may be of practical value for the control of ovarian activity of anoestrous Romney ewes.

The authors wish to acknowledge the assistance of Miss S. Pierard and Mr B. Uljee and Mr D. A. Bilkey in the conduct of the trial. Supplies of MAP sponges (Repromap) were made available by Upjohn (Pty) Ltd.

\section{REFERENCE}

Roberts, E. M. \& Edgar, D. G. (1966) The stimulation of fertile oestrus in anoestrous Romney ewes. I. J. Reprod. Fert. 12, 561. 